\title{
Signal Molecules Crosstalk and the Critical Role of Jasmonic Acid in Triterpenoid Synthesis Inducement of Aspergillus Niger Elicitor in Suspension Cultured Cyclocarya Paliurus Cells
}

\author{
Meng Wang \\ Jiangxi Agricultural University \\ Daobang Tang
}

Guangdong Academy of Agricultural Sciences

QiongQiong Xiong

Jiangxi Agricultutal University

Jiguang Chen

Jiangxi Agricultural University

Xiaoxiang $\mathrm{Xu}$

Jiangxi Agricultural University

Qingfeng Zhang

Jiangxi Agricultural University

\section{Xiangju Zhou}

Jiangxi Agricultural University

Zhongping Yin ( $\square$ yin_zhongping@163.com )

Jiangxi Agricultural University https://orcid.org/0000-0002-8802-4343

Research article

Keywords: Cyclocarya paliurus, Aspergillus Niger Elicitor, signal transduction, triterpenoids, plant cell culture, elicitation

Posted Date: September 3rd, 2020

DOI: https://doi.org/10.21203/rs.3.rs-58155/v1

License: (1) This work is licensed under a Creative Commons Attribution 4.0 International License. Read Full License 


\section{Abstract}

Background: Cyclocarya paliurus (C. paliurus) leaves contain multiple health benefical metabolites, and therefore are often used in functional foods and Chinese herbal medicines. However, breeding difficulties confines its utilization. Consequently, cell suspension culture was developed to produce the bioactive secondary metabolites of $C$. paliurus leaves, but the content was comparatively low. In the present paper, Aspergillus Niger Elicitor (ANE) was used to stimulate the synthesis of triterpenoids in the suspension cultured $C$. paliurus cells, and the signal molecules crosstalk involved in this elicitation was further studied to interpret the underlying mechanism.

Results: Total triterpenoids accumulation of the cultured C. paliurus cells elicited by $200 \mu \mathrm{g} / \mathrm{mL}$ ANE was 9.17 times higher than that of the untreated cells. Nitric oxide (NO), hydrogen peroxide $\left(\mathrm{H}_{2} \mathrm{O}_{2}\right)$ and jasmonic acid (JA) played important roles in the elicitation as signal molecules. Under the ANE stimulation, the concentrations of $\mathrm{NO}, \mathrm{H}_{2} \mathrm{O}_{2}$ and $\mathrm{JA}$ all increased significantly, but presented different change profiles and peaked at different times. Based on series experiments of NO quenching by C-PTIO, $\mathrm{H}_{2} \mathrm{O}_{2}$ blocking by DMTU, and JA synthesis inhibition by IBU and NDGA, together with exogenous NO, $\mathrm{H}_{2} \mathrm{O}_{2}$ and $\mathrm{JA}$ addition experiments, it was deduced that ANE improved triterpenoids synthesis in the suspension cultured $C$. paliurus cells via a complex signal transduction network, in which three deduced and three hypothetical signal transduction pathways might be involved. JA was not only the junction of $\mathrm{NO}$ and $\mathrm{H}_{2} \mathrm{O}_{2}$ signal pathways, but also the critical point in the whole signal network. RNA-seq analysis showed that a total of 3 candidate JA synthesis pathway genes including 1 LOX and $2 O P R$ were found to be significantly up-regulated under the ANE stimulation, along with 5 down-regulated JAZs and 1 upregulated JAR1 regulating to JA signal transduction.

Conclusions: ANE can significantly increase the triterpenoids synthesis in the suspension cultured $C$. paliurus cells. RNA-seq analysis validated the pivotal role of JA in this ANE elicitation. Our results provided references for the further studies on triterpenoids synthesis in $C$. paliurus under ANE treatment.

\section{Background}

Cyclocarya paliurus (Bata1.) Iljinskaja (C. paliurus) is a well-known edible and medicinal herb belonging to the genus of Juglangdaceae, which mainly grows in the south of China [1]. Its leaves contain multiple kinds of bioactive compounds such as triterpenoids [2], flavonoids [3], polysaccharides [4] and polyphenols [5], and therefore display various bioactivities including anti-tumor [6], regulating lipid metabolism [7] and anti-diabetes [2]. Unfortunately, C. paliurus is on the verge of extinction due to difficulties on the reproduction and cultivation, which dramatically limits its use in medicines and foods, and also drives researchers to develop new techniques to better utilize this resources. Plant cell culture technology presents many advantages on the production of plant secondary metabolites, including short production cycle, better controllability, and independently of climate and weather [8], and therefore it is regarded as a feasible method to make full of the $C$. paliurus resources. 
A series of researches focused on the $C$. paliurus resources utilization had been carried out in our laboratory, such as metabolites identification and quantification [9, 10], metabolites bioactivity [11-13], callus inducement and screening [14] and cell suspension culture [15, 16]. Now, a stable cell suspension culture had been established to produce the main bioactive components of $C$. paliurus in our laboratory.

Triterpenoids of $C$. paliurus have been attracting the researcher's attention for its excellent bioactivities [17]. Eight triterpenoids, including arjunolic acid, betulinic acid, corosolic acid, maslinic acid, oleanolic acid, ursolic acid, $\beta$-amyrin and $\beta$-boswellic acid, were identified from the leaves of $C$. paliurus in our previous studies [10]. Among them, five had been found in our suspension cultured $C$. paliurus cells [18]. To further improve the triterpenoids yield, sodium nitroprusside was applied into the cultured medium as an abiotic elicitor, and the results showed that total triterpenoids yield of the elicited cells was 2.14 times that of the control group [19].

Elicitation is one of the most effective ways to stimulate the secondary metabolite synthesis in the plant cell, and therefore is now widely employed to induce novel metabolites or enhance the accumulation of the target metabolites in the plant cell, tissue and organ cultures [20]. According to chemical property, the elicitors are normally classified into two types, including abiotic elicitors (e.g. methyl jasmonate, salicylic acid (SA), $\mathrm{AgNO}_{3}$ and $\mathrm{CaCl}_{2}$ ) and biotic elicitors (e.g. fungal extracts, bacterial extracts and chitin) [21, 22]. These elicitors can trigger defense or stress-induced responses at a low concentration, which can further regulate the expression level of some biosynthesis pathway genes via complex signal transduction networks and finally promote the synthesis of secondary metabolites [20]. Fungal extract is one of the most effective and studied elicitors in the last three decades. Kümmritz et al [23] reported that adding fungal medium filtrates combined with sucrose feeding significantly enhanced triterpenes content of Salvia fruticosa cell suspension culture by approximately $140 \%$, and the triterpenes yield almost reached the level of intact plants. According to Li et al., the glycyrrhetinic acid content of the cultured Glycyrrhiza uralensis adventitious roots raised 1.8 times with the addition of Aspergillus niger elicitors (ANE) [24]. However, up to now the mechanism of ANE elicitation is not well understood, especially the involved signal transduction network.

In the present paper, ANE was used as a biotic elicitor to increase the triterpenoids synthesis in the suspension cultured $C$. paliurus cells. To interpret the elicitation mechanism, the profile changes of four signal molecules concentration were determined in detail after ANE inducing, meanwhile, the crosstalk among these signal molecules was further studied by a series of experiments of signal molecules blocking, as well as experiments of exogenous signal molecules addition. What's more, differentially expressed genes (DEGs) associated with the jasmonic acid (JA) synthesis and transduction were also analyzed to demonstrate the critical role of JA in this elicitation by RNA-sEq. To the best of our knowledge, at present there is no report on the signal molecules crosstalk involved in the ANE elicitation in the suspension cultured $C$. paliurus cells. Our results and analysis provided references for the further studies on the triterpenoids biosynthesis regulation of the cultured plant cells.

\section{Materials And Methods}




\section{Materials}

Suspension cultured cell lines of $C$. paliurus was cultivated and maintained in Jiangxi Key Laboratory of Natural Products and Functional Food (Jiangxi Agricultural University, Nanchang, China).

Aspergillus niger (CGMCC3.0453) was purchased from China General Microbiological Culture Collection Center (CGMCC).

Maslinic acid ( $\geq 98 \%)$, corosolic acid ( $\geq 98 \%)$, betulinic acid $(\geq 98 \%)$, oleanolic acid ( $\geq 98 \%)$ and ursolic acid ( $\geq 98 \%)$ were all purchased from Shanghai Yuanye Bio-Technology Co., Ltd (Shanghai, China).

\section{Cell suspension culture}

According to the method reported by Yin et al. [9], C. paliurus cells were cultured in a basal liquid MS medium (Murashige and Skoog) supplemented with 2, 4 - D (2 - (2, 4 - dichlorophenoxy) acetic acid, 0.5 $\mathrm{mg} / \mathrm{L}), \mathrm{NAA}(1$ - Naphthaleneacetic acid, $0.3 \mathrm{mg} / \mathrm{L}$ ) and $\mathrm{KT}$ ( 6 - Furfurylaminopurine, $1.0 \mathrm{mg} / \mathrm{L}$ ) in the dark at $25 \pm 1^{\circ} \mathrm{C}$ on a rotary shaker at $115 \mathrm{rpm}$, and sub-cultured every 6 days.

\section{Aspergillus niger elicitor preparation}

ANE (Aspergillus niger elicitor) was prepared according to the method of Xiong et al. [25].

\section{Elicitation method of ANE on the cultured C.paliurus cells}

Elicitation was performed in accordance with the method described by Xiong et al. [25]. ANE at a concentration of $200 \mu \mathrm{g} / \mathrm{mL}$ was added into the culture medium on the $4^{\text {th }}$ day after cell inoculation to stimulate the synthesis of triterpenoids. The cultured cells were respectively sampled at $0^{\text {th }}, 20^{\text {th }}, 40^{\text {th }}$, $60^{\text {th }}$ and $80^{\text {th }}$ hour after ANE elicitation for triterpenoids and signal molecules determinations.

\section{Triterpenoids extraction and determination}

Triterpenoids were extracted by ultrasound wave [18]. A total of $0.5 \mathrm{gram}$ fine powder sample was dispersed in $6 \mathrm{ml}$ ethyl acetate and extracted in an ultrasonic extractor at $60^{\circ} \mathrm{C}$ for $30 \mathrm{~min}$. After centrifugation at $4000 \mathrm{r} / \mathrm{min}$ for $10 \mathrm{~min}$, the supernatant was taken out and volatilized to complete dryness at $60^{\circ} \mathrm{C}$, then redissolved in methanol for triterpenoids determination. The triterpenoids determination was carried out according to the HPLC method of Yin et al. [9]. Total triterpenoids content was the sum content of maslinic acid, corosolic acid, betulinic acid, oleanolic acid and ursolic acid.

\section{Signal molecules assay}

A total of four signal molecules, including nitric oxide (NO), hydrogen peroxide $\left(\mathrm{H}_{2} \mathrm{O}_{2}\right)$, Jasmonic acid (JA) and salicylic acid (SA), were assayed by enzyme-linked immunosorbent assay method in the present paper. NO assay kit was purchased from Beyotime Bio-Technology Co., Ltd (Shanghai, China). $\mathrm{H}_{2} \mathrm{O}_{2}, \mathrm{JA}$ 
and SA assay kit were all provided by Yihan Bio-Technology Co., Ltd (Shanghai, China). All determinations were performed according to the instruction of assay kits.

\section{Quenching of NO}

C-PTIO (Enzo life Sciences, Switzerland), a strong quencher of NO, was used to eliminate NO in the cell cultures [26]. 20 minutes before the addition of ANE, C-PTIO solution was put into the culture medium, and the final C-PTIO concentration was controlled at $0.1,1$ and $100 \mu \mathrm{M}$ respectively. The content of triterpenoids, $\mathrm{H}_{2} \mathrm{O}_{2}$, JA and $\mathrm{SA}$ in the cultured cells were respectively determined when the NO was quenched by the added C-PTIO.

\section{Blocking of $\mathrm{H}_{2} \mathrm{O}_{2}$}

DMTU (Sigma-Aldrich, USA) was used as $\mathrm{H}_{2} \mathrm{O}_{2}$ scavenger in this paper [27]. 20 minutes before the ANE elicitation, DMTU (final concentration of $0.5,1$ and $2 \mathrm{mM}$ were set) was added into the culture medium. The changes of triterpenoids accumulation were tested as well as the concentration changes of NO, JA and SA content when $\mathrm{H}_{2} \mathrm{O}_{2}$ were blocked by DMTU, Which were served to explore the role of $\mathrm{H}_{2} \mathrm{O}_{2}$ in triterpenoid synthesis elicitation of ANE.

\section{Inhibition of JA synthesis}

Two inhibitors, named IBU and NDGA, were conjointly used to block JA synthesis in the cultured $C$. paliurus cells $[28,29]$. Three combinations of IBU and NDGA concentration were applied into the culture medium 20 minutes before the ANE elicitation in this paper, including $25 \mu \mathrm{M}$ IBU and $25 \mu \mathrm{M}$ NDGA, $50 \mu \mathrm{M}$ IBU and $50 \mu \mathrm{M} \mathrm{NDGA}$, and $100 \mu \mathrm{M}$ IBU and $100 \mu \mathrm{M}$ NDGA, which was served to investigate the role of JA in the triterpenoid synthesis stimulation of ANE.

\section{Exogenous addition of signal molecules}

Sodium nitroprusside (SNP, Sigma-Aldrich, USA, 99\%) was used as exogenous NO donor to activate NO signal pathway [30]. Methyl jasmonate (MJA, Sigma-Aldrich, USA, 95\%) was applied as JA donor to generate JA signal molecules [31]. SNP, MJA and $\mathrm{H}_{2} \mathrm{O}_{2}$ (Xilong Chemical Co., Ltd. Guangdong, China, $30 \%$ ) were respectively added into the $C$. paliurus cells culture medium at the same time of ANE elicitation as positive signal molecules control group, whose final concentrations were set at $150 \mu \mathrm{M}, 10 \mu \mathrm{M}$ and 50 $\mu \mathrm{M}$ respectively

\section{RNA extraction and sequencing}

The cultured cells were harvested at $20^{\text {th }}$ hour after ANE elicitation and immediately frozen in liquid nitrogen and stored at $-80^{\circ} \mathrm{C}$ for the following total RNA extraction, as well as the untreated cells. Total RNA was extracted from the cultured $C$. paliurus cells using plant RNA purification reagent (Invitrogen, Carlsbad, CA, USA). The quantity and quality of total RNA were determined by Nanodrop 2000 (Thermo Fisher, America) and Agilent 2100. High-quality total RNA used for RNA-seq should have a concentration 
greater than $200 \mathrm{ng} / \mu \mathrm{L}$, and the RNA integrity number (RIN) must reach 7.5, meanwhile OD $260 / 280$ should be between 1.8 and 2.2. Poly (A) mRNA was enriched from total RNA using Oligo (dT) magnetic beads. The enriched mRNA was randomly broken into short fragments and then was used to synthesize the first-strand cDNA using reverse transcriptase and random primers, which was further served to synthesize the second-strand. These synthesized cDNA fragments were purified and dissolved in EB buffer for end repairing and adding of ploy $(A)$, and then connected with sequencing adapters. The suitable fragments were selected for PCR amplification as templates to establish cDNA library. Finally the cDNA library was sequenced using an Illumina HiSeq 4000 platform with the $2 \times 151$ bp paired-end reads.

\section{Reads alignment and De novo assembly}

The raw reads, which were transformed from base calling file, were filtered out to generate clean reads by removing adaptor sequences, ambiguous reads and the low quality reads (quality value $<20$ ). The clean reads were assembled into transcript contigs using the short reads assembling program Trinity software (http://trinityrnaseq.sourceforge.net/, release-20140413), then the contigs were further connected until it could not be extended on either end, which were defined as unigenes.

\section{Function annotation and classification of unigenes}

All assembled unigenes were annotated using BLASTx alignment (e-value<0.00001) against the following publicly available protein databases: NCBI non-redundant (NR), Swiss-Prot, Pfam, eukaryotic orthologous groups (COG) and KEGG. Combining NR annotation with the Blast2GO program [32], GO annotations of the unigenes were obtained. All GO functional classifications were produced by WEGO software [33]. In the meantime, the pathway assignments were performed in conjunction with the KEGG database. When a conflict occurred among the database results, a priority order of alignments was $\mathrm{Nr}$, Swiss-Port, KEGG, GO and COG.

\section{Identification of differentially expressed genes}

Normalized expression levels of the unigenes were calculated as fragment per kilobases of exon model per million mapped reads (FPKM) by the RSEM software [34]. The differential expression analysis of any two groups was analyzed using the EdgeR software and false discovery rate (FDR) method [35]. Afterward, the significantly differentially expressed genes (DEGs) were identified by the threshold of FDR $<0.05$ and $\log 2 \mid$ Fold Change $\mid \geq 1$. To further identify significantly over-represented metabolic pathways or signal transduction pathways, all DEGs were mapped to KEGG database with a threshold E-value of $10^{-5}$ for pathway enrichment analysis.

\section{Results}

\section{Stimulation effects of ANE on the triterpenoids synthesis in the cultured cells}


To further enhance the triterpenoids production, ANE, a widely used biotic elicitor, was applied to stimulate triterpenoids synthesis in the cultured cells. Our results (as showed in Fig.1) indicated that the accumulation of triterpenoids in the cultured $C$. paliurus cells enhanced significantly under the elicitation of ANE at a concentration of $200 \mu \mathrm{g} / \mathrm{mL}$, while the biomass was unaffected. With the time increasing, the yield of total triterpenoids rose first and fell later, and peaked at 60 hours after the ANE addition. The peak total triterpenoids yield of the elicited cells was 9.17 times higher than that of the untreated cells. However, ANE's elicitation mechanism is still unclear. To better understand the mechanism, four signal molecules crosstalk was further investigated as well as the RNA-seq.

\section{Profile changes of four signal molecules concentration under the ANE elicitation}

After the elicitation of $200 \mu \mathrm{g} / \mathrm{mL}$ ANE, the concentrations of $\mathrm{NO}, \mathrm{H}_{2} \mathrm{O}_{2}$ and JA all increased significantly in the cultured $C$. paliurus cells, but presented different change profiles and peaked at different time (as shown in Fig. 2(a-c)). While, SA concentration fell gradually at the beginning, then kept relatively stable and lower than that of the untreated cells until 80 hours post-elicitation (Fig. 2(d)). Consequently, it was deduced that $\mathrm{NO}, \mathrm{H}_{2} \mathrm{O}_{2}$ and $\mathrm{JA}$ was involved in the signal transduction of ANE elicitation as important signal molecules.

NO concentration rise is a common physiological reaction in plant cells when stimulated by elicitors (Xu et al., 2005). Our results (Fig. 2(a)) showed that NO concentration increased swiftly after the addition of ANE, and peaked at the $15^{\text {th }}$ minute, then decreased sharply and maintained at a similar level of the unelicited cells from 4 to 80 hours post-elicitation. Similarly, $\mathrm{H}_{2} \mathrm{O}_{2}$ concentration also enhanced rapidly under the ANE stimulation, and also reached a high concentration at the $15^{\text {th }}$ minute (Fig. 2(b)). Nevertheless, unlike $\mathrm{NO}, \mathrm{H}_{2} \mathrm{O}_{2}$ concentration always kept at a high level from 15 minutes to 80 hours, which was significantly higher than that in the untreated cells (Fig. 2(b)). The concentration changes of JA lagged behind that of $\mathrm{NO}$ and $\mathrm{H}_{2} \mathrm{O}_{2}$ (Fig. 2(a-c)). Within 6 hours after ANE elicitation, JA concentration was almost the same as that in un-elicited cells. From the $7^{\text {th }}$ to $80^{\text {th }}$ hour post-elicitation, JA concentration was obviously higher than that of control group, with two peaks appearing at the $18^{\text {th }}$ and $42^{\text {nd }}$ hour after ANE addition respectively (Fig. 2(c)). The highest concentration of JA occurred at the $42^{\text {nd }}$ post-elicitation. In view of the time sequence changes of these signal molecules, a series of experiments of $\mathrm{NO}$ quenching by C-PTIO, $\mathrm{H}_{2} \mathrm{O}_{2}$ blocking by DMTU, and JA synthesis inhibition by IBU and NDGA were further performed to understand the crosstalk among these signal molecules, together with exogenous $\mathrm{NO}, \mathrm{H}_{2} \mathrm{O}_{2}$ and $\mathrm{JA}$ addition experiments.

\section{Changes causing by NO quenching and exogenous addition}

As shown in Fig.3(a and b), NO concentration decreased gradually with the C-PTIO concentration increasing from 0.1 to $100 \mu \mathrm{mol} / \mathrm{L}$, and fell to the level of the untreated cells at $100 \mu \mathrm{mol} / \mathrm{L}$, but the CPTIO addition and NO change had no influence on the cell growth (biomass was given in Fig. 3(b)). When $100 \mu \mathrm{mol} / \mathrm{L} \mathrm{C}$-PTIO was applied to the cultured cells elicited by $200 \mu \mathrm{g} / \mathrm{mL} \mathrm{ANE}, \mathrm{H}_{2} \mathrm{O}_{2}$ concentration was 
approximately the same as that in the elicited cells, while JA concentration declined significantly, but still obviously higher than that of control group (neither ANE nor C-PTIO was added) (Fig. 3(c and d)). With NO blocked by C-PTIO, triterpenoids yield of the ANE elicited cells reduced by $21.28 \%$ percent, but still markedly higher than that of the control group (Fig. 3(e)).

To further interpret the role of $\mathrm{NO}$ and its relationship with $\mathrm{H}_{2} \mathrm{O}_{2}$ and $\mathrm{JA}, 150 \mu \mathrm{mol} / \mathrm{L} \mathrm{SNP}$ (exgenous NO donor) was added into the culture medium of $C$. paliurus cells. Results (Fig. 3( $\mathrm{f}$ and $\mathrm{g}$ ) indicated that exogenous $\mathrm{NO}$ showed no effect on $\mathrm{H}_{2} \mathrm{O}_{2}$ concentration, while raised the concentration of JA significantly. However, JA concentration in the cells treated by exogenous NO was still lower than that in ANE elicited cells. Under the exogenous NO stimulation, triterpenoids yield was 4.86 times that of the control group, but significantly lower than that of the ANE treated cells (Fig. 3(h)).

Based on the above analysis, the following three conclusions were obtained: firstly, ANE elicitation promoted the synthesis of triterpenoids in C. paliurus cells partly through NO signal pathway; secondly, JA was involved in NO pathway in ANE elicitation, and located in downstream of NO pathway; thirdly, $\mathrm{H}_{2} \mathrm{O}_{2}$ synthesis might be independent on the change of NO concentration.

\section{Changes causing by $\mathrm{H}_{2} \mathrm{O}_{2}$ blocking and exogenous addition}

As DMTU concentration rose from 0.5 to $2 \mathrm{mmol} / \mathrm{L}$, the elimination rate of $\mathrm{H}_{2} \mathrm{O}_{2}$, increased in the $C$. paliurus cell cultures accordingly (Fig. 4(a)). Under the scavenging of $2 \mathrm{mmol} / \mathrm{L} \mathrm{DMTU}, \mathrm{H}_{2} \mathrm{O}_{2}$ concentration in the ANE elicitation cells fell to the level of the un-elicited cells. Meanwhile JA concentration reduced by $14.53 \%$ percent, but still obviously higher than that in the control (Fig. 4(c)). 2 $\mathrm{mmol} / \mathrm{L}$ DMTU showed no significant impact on cell growth ((Fig. 4(b))), but decreasing the triterpenoids yield of the ANE treated cells by $13.76 \%$ percent (Fig. 4(d)). Although triterpenoids accumulation in ANE elicited cells was reduced by $2 \mathrm{mmol} / \mathrm{L}$ DMTU, but still higher than that in the control group (Fig. 4(d)).

When exogenous $50 \mu \mathrm{mol} / \mathrm{L} \mathrm{H}_{2} \mathrm{O}_{2}$ was added into the culture medium of $C$. paliurus cells, JA concentration increased by $11.31 \%$ percent correspondingly, but was still significantly lower than that of the ANE elicited cells (Fig. 4(e)). Stimulated by $50 \mu \mathrm{mol} / \mathrm{L} \mathrm{H}_{2} \mathrm{O}_{2}$, triterpenoids accumulation rose by 78.35 $\%$ percent, however, it was notably lower than that in the ANE treated cells (Fig. 4(f)).

In conclusion, ANE elicitation improved triterpenoids synthesis in C. paliurus cells partly through $\mathrm{H}_{2} \mathrm{O}_{2}$ signal pathway, and the change of $\mathrm{H}_{2} \mathrm{O}_{2}$ concentration could cause the change of JA concentration and finally led to a fluctuation of triterpenoids yield accordingly.

\section{Changes causing by JA synthesis inhibition and exogenous JA addition}

The combined application of IBU and NDGA could effectively as inhibit JA synthesis in the cultured $C$. paliurus cells. With the addition of $100 \mu \mathrm{mol} / \mathrm{L}$ IBU and NDGA, JA concentration in the ANE elicited cells declined to the level of the un-elicited cells (Fig.5(a)), while the cell growth was unaffected (Fig.5(b)). Under the inhibition of $100 \mu \mathrm{mol} / \mathrm{L} \mathrm{IBU}$ and NDGA, triterpenoids yield reduced to $16.69 \mathrm{mg} / 40 \mathrm{~mL}$, which 
was $59.41 \%$ percent of the ANE treated cells, but still significantly higher than that of the control (Fig.5(c)). When $10 \mu \mathrm{mol} / \mathrm{L}$ MJA was used as JA donor in the culture medium, triterpenoids yield improved to $24.33 \mathrm{mg} / 40 \mathrm{~mL}$, which was 4.92 times that of the control (Fig.5(d)).

Comparatively speaking, JA blocking resulted in the biggest decline of triterpenoids yield in the ANE elicited C. paliurus cells (Fig.5(c)), followed by $\mathrm{NO}$ and $\mathrm{H}_{2} \mathrm{O}_{2}$ blocking (Fig.3(e) and Fig.4(d)). Similarly, exogenous $\mathrm{JA}$ addition led to the highest increase of triterpenoids yield in the cultured $C$. paliurus cells (Fig.5(d)), followed by $\mathrm{NO}$ and $\mathrm{H}_{2} \mathrm{O}_{2}$ addition (Fig.3(h) and Fig.4(f)).

Consequently, it was deduced that JA was the critical signal molecule for triterpenoids yield promotion in the ANE elicitation, and the change of JA concentration could cause a notable change of triterpenoids accumulation in the culture $C$. paliurus cells.

\section{Summary of Signal molecules crosstalk and deduced signal transduction pathways involved in ANE elicitation}

Our signal molecules blocking and exogenous addition experiments suggested that $\mathrm{NO}, \mathrm{H}_{2} \mathrm{O}_{2}$ and $\mathrm{JA}$ were all involved in the responses of ANE elicitation in the suspension cultured $C$. paliurus cells; the blocking of any one of $\mathrm{NO}, \mathrm{H}_{2} \mathrm{O}_{2}$ and $\mathrm{JA}$ led to triterpenoids accumulation decline in the ANE elicited cells. Conversely, exogenous addition of any one of $\mathrm{NO}, \mathrm{H}_{2} \mathrm{O}_{2}$ and $\mathrm{JA}$ resulted in triterpenoids synthesis rising, but their induced increments were all lower than that of ANE; both $\mathrm{NO}$ and $\mathrm{H}_{2} \mathrm{O}_{2}$ had apparent impacts on JA synthesis; the change of $\mathrm{NO}$ concentration showed no effect on the $\mathrm{H}_{2} \mathrm{O}_{2}$ synthesis; the influence of JA on triterpenoids synthesis was relatively more significant than that of $\mathrm{NO}$ and $\mathrm{H}_{2} \mathrm{O}_{2}$. Based on the above analyses, three signal transduction pathways were deduced, which were shown in Fig. 6 and described as following: (1) ANE $\rightarrow$ receptor $\rightarrow$ nitric oxide synthase (NOS) $\rightarrow$ NO $\rightarrow$ jasmonic acid synthesis enzymes $\rightarrow \mathrm{JA} \rightarrow \mathrm{TFs} \rightarrow$ triterpenoids synthesis enzymes $\rightarrow$ triterpenoids; (2) ANE $\rightarrow$ receptor $\rightarrow$ NADPH oxidase $\rightarrow \mathrm{H}_{2} \mathrm{O}_{2} \rightarrow$ jasmonic acid synthesis enzymes $\rightarrow \mathrm{JA} \rightarrow$ TFs $\rightarrow$ triterpenoids synthesis enzymes $\rightarrow$ triterpenoids; (3) ANE $\rightarrow$ receptor $\rightarrow$ NADPH oxidase $\rightarrow \mathrm{H}_{2} \mathrm{O}_{2} \rightarrow$ nitric oxide synthase (NOS) $\rightarrow$ NO $\rightarrow$ jasmonic acid synthesis enzymes $\rightarrow \mathrm{JA} \rightarrow \mathrm{TFs} \rightarrow$ triterpenoids synthesis enzymes $\rightarrow$ triterpenoids. In addition, there might be another three hypothetical signal transduction pathways involved in ANE elicitation, which need to be further validated: (1) ANE $\rightarrow$ receptor $\rightarrow$ nitric oxide synthase $(\mathrm{NOS}) \rightarrow \mathrm{NO} \rightarrow \mathrm{TFs} \rightarrow$ triterpenoids synthesis enzymes $\rightarrow$ triterpenoids; (2) ANE $\rightarrow$ receptor $\rightarrow \mathrm{NADPH}$ oxidase $\rightarrow \mathrm{H}_{2} \mathrm{O}_{2} \rightarrow$ TFs $\rightarrow$ triterpenoids synthesis enzymes $\rightarrow$ triterpenoids; (3) ANE $\rightarrow$ receptor $\rightarrow$ other pathways independent of $\mathrm{NO}, \mathrm{H}_{2} \mathrm{O}_{2}$ and $\mathrm{JA} \rightarrow$ TFs $\rightarrow$ triterpenoids synthesis enzymes $\rightarrow$ triterpenoids. In summary, ANE elicitation improved the triterpenoids accumulation in the suspension cultured $C$. paliurus cells via a complex signal transduction network, in which $\mathrm{NO}, \mathrm{H}_{2} \mathrm{O}_{2}$ and JA were involved, and JA was the critical signal molecule.

\section{RNA-seq and de novo assembly}


Transcriptome sequencing technology, also known as RNA-seq, is now widely used to explore the mechanism of biological phenomena from the perspective of gene expression difference [36]. In the present paper, three cDNA libraries from the cultured C. paliurus cells, named CK (control), 20h (cells elicited for $20 \mathrm{~h}$ ), $60 \mathrm{~h}$ (cells elicited for $60 \mathrm{~h}$ ) respectively, were sequenced using Illumina Hiseq 4000 platform, which generated $65,074,242,66,016,592$ and $53,951,932$ raw reads separately (Table S1). After data filtering and stringent quality evaluation, clean reads were obtained. Subsequently, using Trinity program, these clean reads were assembled into 88,144 transcripts with an N50 of 1,590 bp and the average length of $869 \mathrm{bp}$, which were then joined into 67230 unigenes with an N50 of $1375 \mathrm{bp}$ and the average length of $744 \mathrm{bp}$ (Table S2). Furthermore, the length and number of transcripts and unigenes were statistically analyzed. As shown in Fig.S1, the length of transcripts and unigenes ranged from 201 to $17,098 \mathrm{bp}$ and the majority distributed in $201-400 \mathrm{bp}$, accounting for $45.56 \%$ and $52.99 \%$ respectively. The above-mentioned data indicated that the generated unigenes in our experiments were of fine quality, and therefore suitable for further annotation.

\section{Function annotations and classifications of unigenes}

A total of 33,470 unigenes (accounting for $49.78 \%$ of all unigenes) were successfully annotated against seven public databases such as NR, Swiss-Prot, KOG KEGG, GO, COG (Table S3). The results of unigenes homology searches against the NR database were shown in Fig.S2, including the similar, E-value and species distribution. As seen in Fig.S2(c), 3972 annotated unigenes of $C$. paliurus had the first top matches with sequences from Vitis vinifera, followed by the Theobroma cacao (3417 unigenes), Prunus persica (2702 unigenes), Prunus mume (2548 unigenes) and Morus notabilis (1807 unigenes).

All C. paliurus unigenes were aligned to the COG database for prediction and classification by possible function. Overall, a total of 7,694 unigenes (11.44\%) were classified into $25 \mathrm{COG}$ functional categories (Fig S3(a)).Our results indicated that 1,008 annotated unigenes (13.10\%) fell into "General function prediction only" group, which was the largest among the $25 \mathrm{COG}$ functional categories, followed by "Signal transduction mechanisms" $(966,10.11 \%)$. It should be noted that no unigenes was classified as "Extracellular structures" and "Nuclear structure", which need to be further studied.

According to the annotation against Gene Ontology (G0), altogether 19398 unigenes were classified into three main categories: "cellular component" (42,253 unigenes, 32.91\%), "molecular function" (24,703 unigenes, 19.24\%), and "biological process" (61440 unigenes, 47.85\%), which were further divided into 65 sub-categories. (Fig.S3 (b)).Within the cellular component category, cell sub-category $(8,221$ unigenes, $19.46 \%)$ and cell part sub-category $(8,221$ unigenes, $19.46 \%)$ were the two most significant representation. Among the molecular function unigenes, the majority were classified into "binding subcategory" (11,100 unigenes, $44.93 \%)$ and "catalytic activity sub-category" (10,098 unigenes, $40.88 \%)$.

To better understand the biological functions of these unigenes in the cultured $C$. paliurus cells, a total of 13,634 unigenes (20.28\%) were mapped to 348 KEGG pathways and divided into five branches including Metabolism; Genetic Information Processing, Environmental Information Processing, Environmental Information Processing, Cellular the Processes and Organismal Systems (Fig.S3 (c)). The most 
represented pathways were Metabolic pathways (2778 unigenes, $18.74 \%$ ), followed by biosynthesis of secondary metabolites (1336 unigenes, 9.80\%). In addition, 29 metabolic pathways play a significant role in the growth and metabolism of the cultured cells (Table S4), such as phenylpropanoid biosynthesis (179 unigenes), terpenoid backbone biosynthesis (75 unigenes) and flavonoid biosynthesis (42 unigenes). Our annotation against KEGG provided lots of useful information to interpret the metabolic characteristics of the cultured $C$. paliurus cells.

\section{Overall analysis of differentially expressed genes}

From the perspective of differentially expressed genes (DEGs), ANE elicitation caused great changes in metabolism related genes expression (Fig. S4), which might further result in markedly changes of the metabolites synthesis and accumulation in the cultured C. paliurus cells. A total of 24,788 DEGs were found between the un-elicited cells and elicited cells treated for 20 hours, which consisted of 12,699 upregulated DEGs and 12,089 down-regulated DEGs. Among these DEGs, 774 genes were significantly upregulated, while 876 were significantly down-regulated. Similarly, between the un-elicited cells and elicited cells treated for 60 hours, there were 340 significantly up-regulated genes and 129 significantly downregulated genes. Furthermore, cells elicited for 20 hours showed different gene expression profile by comparison with that elicited for 60 hours. Between these two treated groups, 406 significant upregulation and 224 significant down-regulation genes were identified. The three groups of DEGs were further analyzed. Among them, 1650, 469 and 630 genes were significantly differentially expressed, and 35 genes belonged to the differentially expressed genes in three samples. The vene diagram is shown in Fig. S5.

\section{Analysis of DEGs involved in JA synthesis pathway under ANE treatment}

To further validate the key role of JA in the responses of ANE elicitation in C. paliurus cells, the expression levels of JA synthesis-related genes such as $L O X, A O S, A O C$, and $O P R$ were detected using comparative transcriptome sequencing. A total of 7 annotated candidate $L O X$ unigenes were up-regulated, among which 1 were significantly up-regulated (Table 1). Within the 6 up-regulated $O P R$ unigenes, 2 were found to be significantly up-regulated. Meanwhile, the expression of $2 A O C$ and 1 AOS unigenes increased, but not significantly (Table 1). The above DEGs analysis associated with JA synthesis was in consistence with the determination data of JA concentration in the elicited cells. Our results indicated that ANE elicitation activated the expression of JA synthesis pathway genes, which finally enhanced the triterpenoids accumulation in the culture cells.

\section{Analysis of DEGs involved in JA signal transduction pathway under ANE treatment}

Researches showed that JAZ and JAR1 were key transcription factors in JA signal transduction pathway, and played critical roles in the synthesis of secondary metabolites [37, 38]. In the present paper, a total of $7 \mathrm{JAZ}$ candidate unigenes were annotated, among which 5 were found to be down-regulated, and 1 kept almost unchanged, while 1 was up-regulated (Table 2). In addition, one JAR1 candidate unigene (c39500_g1) was annotated and observed to be up-regulated, whose FPKM increased from 48.614 to 
77.295 at the $20^{\text {th }}$ hours after ANE elicitation (Table 2). Consequently, it was speculated that the downregulation of JAZs together with the up-regulation of JAR1 mediated the ANE elicitation signal transduction, and led to the rising of triterpenoids synthesis in the cultured cells, which further validated the above deduced JA signal pathway and the critical role of JA in ANE elicitation.

\section{Discussion}

Fungal elicitor, as a highly effective stimulator, can trigger rapid defense responses when applied to in vitro plant cell, tissue and organ cultures, and thus stimulate the secondary metabolites synthesis by activating the expression of specific genes $[39,40]$. Our elicitation experiment suggested that ANE can significantly improve the triterpenoids yield of the cultured $C$. paliurus cells, and therefore has a promising application prospect in the production of plant-derived triterpenoids. However, more investigations are still needed to better understand the elicitation mechanism. Our previous report showed that ANE elicitation up-regulated the expression of triterpenoid synthesis pathway genes, and therefore enhanced the triterpenoid accumulation in the cultured $C$. paliurus cells [41], but the involved signal mechanism causing the triterpenoid synthesis genes up-regulation hasn't been revealed yet.

Researches indicated that there are four common signal molecules, including $\mathrm{NO}, \mathrm{H}_{2} \mathrm{O}_{2}$, JA and SA, which mediate signal transduction when plants face various environmental stresses, such as fungal invasion, insect attack, drought, osmotic pressure [42-44]. Usually, these signal molecules play their roles in the complicated signal transduction network harmoniously, and result in differential expression of some related key genes, which further causes various physiological responses in the plants $[45,46]$.

Signal transduction is a very complex biological process, and therefore has been attracting many researchers' attention in recent decades. Domingos et al. [47] comprehensively reviewed the characteristics, signal transduction pathways and mechanisms, and functions of $\mathrm{NO}$ as a plant signal molecules, and pointed out that NO played an important role in responses of plants facing various kinds of biotic and abiotic stress. Turner et al. [48] gave a detailed elaboration on JA signal pathway, as well as JA's biosynthesis and regulation, signaling functions, and relationship with other signal molecules like SA and ethylene. Although lots of related researches have been well carried out, signal transduction mechanisms such as signal molecules crosstalk have not been fully understood yet, because numerous highly complicated pathways are involved as well as various signal molecules and related proteins. What's more, there are too many plant species in the world, and different plant may have different transduction mechanisms.

The research of $\mathrm{Xu}$ and Dong [49] suggested that nitric oxide mediated the fungal elicitor-induced taxol biosynthesis in the $T$. chinensis suspension cultured cells through both reactive oxygen speciesdependent and -independent signal pathways. As shown in their report, both NO quenching and reactive oxygen species (ROS, including $\mathrm{H}_{2} \mathrm{O}_{2}$ ) blocking inhibited the elicitor-induced taxol production, which was in accordance with the results of our experiment performed in the suspension cultured $C$. paliurus cells. Their data also showed that $\mathrm{NO}$ quenching suppressed the $\mathrm{H}_{2} \mathrm{O}_{2}$ synthesis, and exogenous NO addition 
increased the $\mathrm{H}_{2} \mathrm{O}_{2}$ accumulation, however according to our results, the change of NO concentration had no effect on the $\mathrm{H}_{2} \mathrm{O}_{2}$ synthesis. According to the schematic representation of action mode of elicitor in plant cell given by Halder et al. [20], NO synthesis was the downstream event of the ROS burst under elicitation, which coincided with our conclusion. These different phenomena and results may be caused by plant species differences or other unknown reasons, and further studies are still needed.

Both SA and JA are important signal molecules associated with plant defense responses [50]. Our previous studies showed that any one of SA and JA inducing could stimulate the synthesis of secondary metabolites [51]. However, according to Li et al. [52], there was antagonism between SA and JA pathways in A. thaliana in response to elicitation, and WRKY70 acted as an activator of SA-induced genes and a repressor of JA-responsive genes to integrate signals from these mutually antagonistic pathways. Similar results were reported by Xu et al. [53]. In our ANE elicitation experiments, JA concentration increased significantly after the ANE addition, and played a critical role in stimulating triterpenoids synthesis, while SA concentration was lower than that of the untreated cells. Our results also confirmed the antagonism between SA and JA pathways.

In this study, JA was found to be not only the junction of $\mathrm{NO}$ and $\mathrm{H}_{2} \mathrm{O}_{2}$ signal pathways but also the critical point in the whole signal network of ANE elicitation. Researches indicated that JA, as an important endogenous phytohormone, was synthesized in plant using a-linolenic acid as starting compound [54], and a series of cascade enzymes of its synthesis pathways were involved, including $\angle O X, A O S, A O C$, and $\operatorname{OPR}[55,56]$, which were also identified in our elicited $C$. paliurus cells (Table 1$)$. Our RNA-seq analysis showed that a total of 3 candidate JA synthesis pathway genes including 1 LOX and 2 OPR were found to be significantly up-regulated under the ANE stimulation,, as well as 5 down-regulated JAZs and 1 upregulated JAR1 relating to JA signal transduction, which further validated the key role of JA in response to ANE elicitation. JAs (jasmonates) usually refer to a category of organic compounds derived from JA, including jasmonic acid (JA), methyl jasmonate (MeJA), and jasmonic acid isoleucine (JA-lle), which acted as ubiquitous and conserved regulators for the production of secondary metabolites in the most majority of plants, from gymnosperms to angiosperms [37, 57]. It is generally recognized that JA shows its effects through a bioactive form - JA-lle, which is synthesized from JA and isoleucine under the catalysis of JA amino acid synthetase (JAR1) [37, 38]. Normally, JA-lle concentration is very low, and MYC2 is bound by jasmonate ZIM-domain protein (JAZ) and presents in an inactive form; when the JA-lle concentration increases to a certain level under stimulation, the COI1 protein of SCF ${ }^{\mathrm{CO} 11}$ complex interacts physically with JAZ protein and make the latter to be labeled with ubiquitin, which causes MYC2 to be freed from JAZ and JAZ to be degraded by 26S-proteasome; the free MYC2 released from JAZ activates the expression of the early jasmonate-response genes and finally improved the synthesis of secondary metabolites to adapt to the environment changes [37, 57-60]. Our results also indicated that JA mediated the signal transduction of ANE elicitation, in which TFs like JAZ and JAR played important roles. Meanwhile, MYC2 were also annotated in our ANE treated cells, but its expression declined slightly at the 20th hour after elicitation (Table 2). However, further studies are still needed to interpret the underlying mechanism of these TFs associated with JA signal transduction pathways. 


\section{Conclusion}

ANE elicitation significantly enhanced the triterpenoids accumulation in the suspension cultured $C$. paliurus cells. $\mathrm{NO}, \mathrm{H}_{2} \mathrm{O}_{2}$ and $\mathrm{JA}$ were all involved in this elicitation as important signal molecules. Three related signal pathways were deduced based on a series of experiments of signal molecules blocking and exogenous addition, together with three hypothetical signal transduction pathways involved in ANE elicitation. JA was not only the junction of $\mathrm{NO}$ and $\mathrm{H}_{2} \mathrm{O}_{2}$ signal pathways but also the critical point in the whole signal network of ANE elicitation. RNA-seq analysis further validated the pivotal role of JA in ANE elicitation. As far as we know, up to now this paper is the first report on the signal molecules crosstalk involved in the ANE elicitation in the suspension cultured $C$. paliurus cells.

\section{Declarations}

\section{Acknowledgments}

The authors are grateful for the assistance in RNA-seq determination and its related analysis from Sangon Biotech (Shanghai) Co., Ltd.

\section{Authors' contributions}

ZY and JC conceived the idea and designed the experiments. MW and QX performed the experiments. $M W, X X$ and $X Z$ contributed to data analysis. All authors discussed the results and commented on the manuscript. All authors read and approved the final manuscript.

\section{Funding Statement}

The authors are grateful for the support from the National Natural Science Foundation of China (31960515) and Jiangxi Province Natural Science Foundation (20192BAB204004)

\section{Availability of data and materials}

All relevant data are within the paper and its Supporting Information files.

\section{Ethics approval and consent to participate}

Not applicable

\section{Consent for publication}

Not applicable

\section{Competing interests}

The authors declare that they have no competing interests. 


\section{References}

1. Xie MY, Xie JH. Review about the research on Cyclocarya paliurus (Batal.) Iljinskaja. J Food Sci and Biotechnol. 2008; 1: 113-121.

2. Sun H, Tan J, Lv W, Li J, Wu J, Xu J, Xuan T. Hypoglycemic triterpenoid glycosides from Cyclocarya paliurus (Sweet Tea Tree). Bioorg Chem.2019; 95: 103493. https://doi.org/10.1016/j.bioorg.2019.103493.

3. Xie, J, Wang, W., Dong, C., Huang, L., Wang, H., Li, C., Xie, M. Protective effect of flavonoids from Cyclocarya paliurus leaves against carbon tetrachloride-induced acute liver injury in mice. Food Chem Toxicol. 2018; 119: 392-399.https://doi.org/10.1016/j.fct.2018.01.016.

4. Xie JH, Liu X, Shen, MY, Nie SP, Zhang H, Li C, Xie MY. Purification, physicochemical characterisation and anticancer activity of a polysaccharide from Cyclocarya paliurus leaves.Food Chem. 2013; 136(3): 1453-1460. https://doi.org/10.1016/j.foodchem.2012.09.078.

5. Liu Y, Chen P, Zhou M, Wang, T., Fang, S., Shang, X., Fu, X. Geographic variation in the chemical composition and antioxidant properties of phenolic compounds from Cyclocarya paliurus (Batal) Iljinskaja leaves. Molecules, 2018; 23(10).https://doi.org/10.3390/molecules23102440.

6. Xuan TY, Tan J, Sun HH, Yang C, Lv WY, Zhang JH, Zhu GZ. Cyclocarioside O-Q, three novel secodammarane triterpenoid glycosides from the leaves of Cyclocarya paliurus. Nat Prod Res, 2019;1-7. https://doi.org/10.1080/14786419.2019.1616722.

7. Yang ZW, Ouyang KH, Zhao J, Chen $\mathrm{H}$, Xiong L, Wang WJ. Structural characterization and hypolipidemic effect of Cyclocarya paliurus polysaccharide in rat. Int J biol macromol, 2016;91:10731080. https://doi.org/10.1016/j.ijbiomac.2016.06.063.

8. Hidalgo D, Sanchez R, Lalaleo L, Bonfill M, Corchete P, Palazon J. Biotechnological production of pharmaceuticals and biopharmaceuticals in plant cell and organ cultures. Curr med chem, 2018;25(30):3577-3596. https://doi.org/ 10.2174/0929867325666180309124317.

9. Yin ZP, Xiong QQ, Shangguan XC, Chen JG. Chemical fingerprint and determination of triterpenoids in cultured Cyclocarya paliurus cells by high-performance liquid chromatography. Anal Lett, 2017;50(5):748-760. https://doi.org/ 10.1080/00032719.2016.1199026.

10. Li T, Shangguan XC, Yin ZP, Chen JG, Jiang Y. The separation and identification of triterpeniods from leaves of Cyclocarya paliurus. Acta Agric Univ Jiangxiensis. 2013;33(2):338-349.

11. Xiong L, Ouyang KH, Jiang Y, Yang ZW, Hu WB, Chen H, Wang WJ. Chemical composition of Cyclocarya paliurus polysaccharide and inflammatory effects in lipopolysaccharide-stimulated RAW264.7 macrophage. Int J biol macromol. 2018;107: 1898-1907. https://doi.org/ 10.1016/j.ijbiomac.2017.10.055.

12. Hu WB, Ouyang KH, Wu GQ, Chen H, Xiong L, Liu X, Wang WJ. Hepatoprotective effect of flavonoidenriched fraction from Cyclocarya paliurus leaves on LPS/D-GaIN-induced acute liver failure. J Funct Foods, 2018;48: 337-350. https://doi.org/ 10.1016/j.jff.2018.07.031. 
13. Yang Z, Wang J, Li J, Xiong L, Chen H, Liu X, Wang W. Antihyperlipidemic and hepatoprotective activities of polysaccharide fraction from Cyclocarya paliurus in high-fat emulsion-induced hyperlipidaemic mice. Carbohyd polym. 2018;183: 11-20. https://doi.org/ 10.1016/j.carbpol.2017.11.033.

14. Shangguan XC, Guo CM, Yang WY, Jiang Y, Shen YG. Effects of basic media and culture conditions on callus growth and flavonoid content of Cyclocarya paliurus. J Fujian Agric and Forestry Univ, 2006;6.

15. Ren M, Shangguan XC, Chen JG, Jiang Y, Wu S, Yin ZP. Effects of Several Factors on the Growth of Cyclocarya paliurus Suspension Cells. Acta Agriculturae Boreali-Occidentalis Sinica, 2012;21(5):179184.

16. Yin ZP, Shangguan XC, Chen JG, Zhao, Q., Li, DM. Growth and triterpenic acid accumulation of Cyclocarya paliurus cell suspension cultures. Biotechnol. Bioprocess Eng. 2013;18:606-614. https://doi.org/10.1007/s12257-012-0751-5.

17. Jiang $C$, Wang $Y$, Jin Q, Zhang D, Gao M, Yao N, Ma S. Cyclocarya paliurus triterpenoids improve diabetes-induced hepatic inflammation via the Rho-kinase dependent pathway. Front Pharmacol.2019; 10: 811. https://doi.org/ 10.3389/fphar.2019.00811.

18. Yin ZP, Shangguan XC, Chen JG, Wu S, Li D. Separation and identification of triterpenic acids from suspended cultured cells of Cyclocarya paliurus. Scientia Silvae Sinicae. 2013;49:23-28.

19. Guo CM, Yin ZP, Shangguan XC, Chen JG, Fu, X. Effect of Sodium Niterprusside on the Biosynthesis of Triterpenic Acids in Suspended Cultured Cyclocarya paliurus Modern Food Sci \& Techno.2014;30(4):68-73+92.

20. Halder M, Sarkar S, Jha S. Elicitation: A biotechnological tool for enhanced production of secondary metabolites in hairy root cultures. Eng Life Sci. 2019;19(12): 880-895. https://doi.org/ 10.1002/elsc.201900058.

21. Buraphaka H, Putalun W. Stimulation of health-promoting triterpenoids accumulation in Centella asiatica (L.) Urban leaves triggered by postharvest application of methyl jasmonate and salicylic acid elicitors. Ind Crop Prod.2020; 146: 112171. https://doi.org/ 10.1016/j.indcrop.2020.112171.

22. El-Bialy $\mathrm{H}$, El-Bastawisy $\mathrm{H}$. Elicitors stimulate paclitaxel production by endophytic fungi isolated from ecologically altered Taxus baccata. J Radiat Res and Appl Sc.2020; 13(1): 79-87. https://doi.org/ 10.1080/16878507.2019.1702244.

23. Kümmritz S, Louis M, Haas C, Oehmichen F, Gantz S, Delenk H, Steingroewer J. Fungal elicitors combined with a sucrose feed significantly enhance triterpene production of a Salvia fruticosa cell suspension. Appl Microbiol Biot.2016; 100(16): 7071-7082. https://doi.org/ 10.1007/s00253-0167432-9.

24. Li J, Wang J, Li JX, Liu DH, Li HF, Gao WY, Li JL, Liu SJ. Aspergillus niger enhance bioactive compounds biosynthesis as well as expression of functional genes in adventitious roots of Glycyrrhiza uralensis Fisch. Appl Biochem Biotech.2016; 178(3): 576-593. https://doi.org/ 10.1007/s12010-015-1895-5. 
25. Xiong QQ, Yin ZP, Chen JG, Shangguang XC, Jiang Y, Peng DY. Aspergillus Niger inducer stimulate the biosynthesis of triterpenoids in suspension-cultured Cyclocarya paliurus Food Sci \& Technol. 2016;41: 7-13.

26. Xu MJ, Dong JF, Zhu MY. Nitric oxide mediates the fungal elicitor-induced hypericin production of Hypericum perforatum cell suspension cultures through a jasmonic-acid-dependent signal pathway. Plant Physiol. 2005;139(2): 991-998. https://doi.org/ 10.1104/pp.105.066407.

27. Lin WL, Hu XY, Zhang WQ, Rogers WJ, Cai WM. Hydrogen peroxide mediates defence responses induced by chitosans of different molecular weights in rice. J Plant Physiol. 2005;162(8):937-944. https://doi.org/ 10.1016/j.jplph.2004.10.003.

28. Nojiri H, Sugimori M, Yamane H, Nishimura Y, Yamada A, Shibuya N, Omori T. Involvement of jasmonic acid in elicitor-induced phytoalexin production in suspension-cultured rice cells. Plant Physiol.1996; 110(2): 387-392. https://doi.org/ 10.1104/pp.110.2.387.

29. Menke F, Parchmann S, Mueller M, Kijne J, Memelink J. Involvement of the octadecanoid pathway and protein phosphorylation in fungal elicitor-induced expression of terpenoid indole alkaloid biosynthetic genes in Catharanthus roseus. Plant physiol.1999;119(4):1289-1296. https://doi.org/ 10.1104/pp.119.4.1289.

30. Bethke P, Libourel I, ReinöhI V, Jones R. Sodium nitroprusside, cyanide, nitrite, and nitrate break Arabidopsis seed dormancy in a nitric oxide-dependent manner. Planta. 2006;223(4):805-812. https://doi.org/ 10.1007/s00425-005-0116-9.

31. Creelman R, Tierney ML, Mullet JE. Jasmonic acid/methyl jasmonate accumulate in wounded soybean hypocotyls and modulate wound gene expression. Proc Nati Acad Sci.1992; 89(11):49384941. https://doi.org/ 10.1073/pnas.89.11.4938.

32. Conesa A, Götz S, García-Gómez J, Terol J, Talón M, Robles M. Blast2GO: a universal tool for annotation, visualization and analysis in functional genomics research. Bioinformatics.2005; 21(18): 3674-3676. https://doi.org/10.1093/bioinformatics/bti610.

33. Ye J, Fang L, Zheng HK, Zhang Y, Chen J, Zhang ZJ, Wang J. WEGO: a web tool for plotting GO annotations. Nucleic Acids Res.2006; 34, 293-297. https://doi.org/10.1093/nar/gkl031.

34. Mortazavi A, Williams BA, McCue K, Schaeffer L, Wold BJ. Mapping and quantifying mammalian transcriptomes by RNA-Seq. Nat methods.2008;5(7):621-628. https://doi.org/10.1038/nmeth.1226.

35. Reiner A, Yekutieli D, Benjamini Y. Identifying differentially expressed genes using false discovery rate controlling procedures. 2003;19(3): 368-375. https://doi.org/10.1093/bioinformatics/btf877.

36. Hrdlickova R, Toloue M, Tian B. RNA-Seq methods for transcriptome analysis. WIRES RNA. 2017;8(1): e1364. https://doi.org/ 10.1002/wrna.1364.

37. Afrin S, Huang J, Luo Z. JA-mediated transcriptional regulation of secondary metabolism in medicinal plants. Sci Bull.2015; 60(12): 1062-1072. https://doi.org/ 10.1007/s11434-015-0813-0.

38. Staswick P, Tiryaki I. The oxylipin signal jasmonic acid is activated by an enzyme that conjugates it to isoleucine in Arabidopsis. The Plant Cell.2004; 16(8): 2117-2127. https://doi.org/10.1105/tpc.104.023549. 
39. Liang C, Chen C, Zhou P, Xu L, Zhu J, Liang J, Yu R. Effect of Aspergillus flavus fungal elicitor on the production of terpenoid indole alkaloids in Catharanthus roseus cambial meristematic cells. Molecules.2018; 23(12): 3276. https://doi.org/ 10.3390/molecules23123276.

40. Li J, Liu S, Wang J, Li J, Liu D, Li J, Gao W. Fungal elicitors enhance ginsenosides biosynthesis, expression of functional genes as well as signal molecules accumulation in adventitious roots of Panax ginseng C. A. Mey. J Biotechnol.2016; 239: 106-114. https://doi.org/ 10.1016/j.jbiotec.2016.10.011.

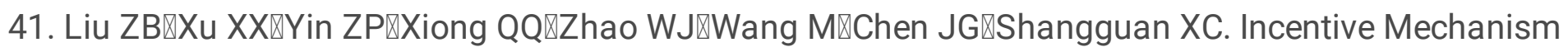
of Triterpenoid Synthesis by Antioxidant Response in the Cultured Cyclocarya paliurus Cells under the Elicitation of Aspergillus niger Sci Technol Food Ind. 2016;3:7-13.

42. Saxena I, Srikanth $\mathrm{S}$, Chen Z. Cross talk between $\mathrm{H}_{2} \mathrm{O}_{2}$ and interacting signal molecules under plant stress response. Front Plant Sci.2016; 7: 570. https://doi.org/ 10.3389/fpls.2016.00570.

43. Yan K, He L, Yang K. Effects of $\mathrm{SA}$ and $\mathrm{H}_{2} \mathrm{O}_{2}$ Mediated Endophytic Fungal Elicitors on Essential Oil in Suspension Cells of Cinnamomum longepaniculatum. OALib Journal. 2020; 7(1):1-12. https://doi.org/ 10.4236/oalib.1106009.

44. Zhang Y, Li X. Salicylic acid: biosynthesis, perception, and contributions to plant immunity. Curr opinn plant boil.2019; 50: 29-36. https://doi.org/10.1016/j.pbi.2019.02.004.

45. Lv F, Li S, Feng J, Liu P, Gao, Z., Yang, Y., Wei, J. Hydrogen peroxide burst triggers accumulation of jasmonates and salicylic acid inducing sesquiterpene biosynthesis in wounded Aquilaria sinesis. J Plant Physiol.2019; 167-175. https://doi.org/10.1016/j.jplph.2019.02.006.

46. Astier J, Loake G, Velikova V, Gaupels F. Editorial: Interplay between NO signaling, ROS, and the antioxidant system in plants. Front Plant Sci.2016; 7: 1731. https://doi.org/ 10.3389/fpls.2016.01731.

47. Domingos P, Prado A, Wong A, Gehrin C, Feijo J. Nitric oxide: a multitasked signaling gas in plants. Mol Plant.2015; 8(4): 506-520. https://doi.org/10.1016/j.molp.2014.12.010.

48. Turner JG, Ellis C, Devoto A. The jasmonate signal pathway. The Plant Cell.2002; 14 (suppl 1): S153S164. https://doi.org/10.1105/tpc.000679.

49. Xu, MJ, Dong, JF. Nitric oxide mediates the fungal elicitor-induced Taxol biosynthesis of Taxus chinensis suspension cells through the reactive oxygen species-dependent and-independent signal pathways. Chinese Sci Bull.2006; 51(16): 1967-1975.https://doi.org/10.1007/s11434-006-2081-5.

50. Kunkel B, Brooks D. Cross talk between signaling pathways in pathogen defense. Curr opin plant boil. 2002;5(4):325-331. https://doi.org/ 10.1016/S1369-5266(02)00275-3.

51. Liu ZB, Chen JG, Yin ZP, Shangguan XC, Peng DY, Lu T, Lin P. Methyl jasmonate and salicylic acid elicitation increase content and yield of chlorogenic acid and its derivatives in Gardenia jasminoides cell suspension cultures. PCTOC. 2018; 134(1):79-93. https://doi.org/10.1007/s11240-018-1401-1.

52. Li J, Brader G, Palva ET. The WRKY70 transcription factor: a node of convergence for jasmonatemediated and salicylate-mediated signals in plant defense. The Plant Cell. 2004;16(2):319-331. https://doi.org/10.1105/tpc.016980. 
53. Xu MJ, Dong JF, Zhu MY. Nitric oxide mediates the fungal elicitor-induced puerarin biosynthesis in Pueraria thomsonii Benth. suspension cells through a salicylic acid (SA)-dependent and a jasmonic acid (JA)-dependent signal pathway. Sci China Ser C.2006; 49(4): 379-389. https://doi.org/10.1007/s11427-006-2010-5.

54. Liechti R, Farmer E. Jasmonate biochemical pathway. Sci Signal. 2006; 2006(322). https://doi.org/10.1126/stke.3222006.cm3.

55. Mueller M. Enzymes involved in jasmonic acid biosynthesis. Physiol Plantarum.1997; 100(3): 653663. https://doi.org/10.1111/j.1399-3054.1997.tb03072.x.

56. Toyoda K, Kawanishi Y, Kawamoto Y, Kurihara C, Yamagishi N, Tamura A, Shiraishi T. Suppression of mRNAs for lipoxygenase (LOX), allene oxide synthase (AOS), allene oxide cyclase (AOC) and 12-oxophytodienoic acid reductase (OPR) in pea reduces sensitivity to the phytotoxin coronatine and disease development by Mycosphaerella pinodes. J Gen Plant Pathol.2013; 79(5): 321-334. https://doi.org/10.//s10327-013-0460-8.

57. Avanci N, Luche D, Goldman G, Goldman M. Jasmonates are phytohormones with multiple functions, including plant defense and reproduction. Genet Mol Res. 2010; 9(1): 484-505. https://doi.org/10.4238/vol9-1gmr754.

58. Major I, Yoshida Y, Campos M, Kapali G, Xin X, Sugimoto K, Howe G. Regulation of growth-defense balance by the JASMONATE ZIM-DOMAIN (JAZ)-MYC transcriptional module. New Phytol. 2017;215(4): 1533-1547. https://doi.org/10.1111/nph.14638.

59. Ge Q, Zhang Y, Hua WP, Wu Y, Jin X, Song SH, Wang Z. Combination of transcriptomic and metabolomic analyses reveals a JAZ repressor in the jasmonate signaling pathway of Salvia miltiorrhiza. Scientific reports. 2015;5(1):14048. https://doi.org/10.1038/srep14048.

60. Commault A, Fabris M, Kuzhiumparambil U, Adriaans J, Pernice M, Ralph P. Methyl jasmonate treatment affects the regulation of the 2-C-methyl-D-erythritol 4-phosphate pathway and early steps of the triterpenoid biosynthesis in Chlamydomonas reinhardtii. Algal research. 2019;39: 101462. https://doi.org/10.1016/j.algal.2019.101462.

\section{Tables}


Table 1

Summary of differentially expressed genes in JA synthesis pathway of suspension cultured C. paliurus cells

\begin{tabular}{|c|c|c|c|c|}
\hline Unigene name & Unigene code & FPKM of CK & FPKM of $E_{20 h}$ & Trends \\
\hline \multirow[t]{7}{*}{ LOX } & c41476_g2 & 32.342 & 36.76 & up \\
\hline & c33483_g1 & 16.031 & 16.534 & up \\
\hline & c41476_g3 & 74.344 & 329.943 & up* \\
\hline & c17385_g1 & 22.275 & 25.741 & up \\
\hline & c33483_g1 & 16.031 & 16.534 & up \\
\hline & C45031_g1 & 17.787 & 22.979 & up \\
\hline & c17385_g1 & 22.275 & 25.741 & up \\
\hline AOS & c43559_g1 & 0.618 & 2.196 & up \\
\hline \multirow[t]{2}{*}{$\mathrm{AOC}$} & c10965_g1 & 38.972 & 41.961 & up \\
\hline & c35833_g1 & 58.4 & 68.947 & up \\
\hline \multirow[t]{6}{*}{ OPR } & c24740_g1 & 8.136 & 16.473 & up \\
\hline & c24761_g1 & 3.648 & 4.199 & up \\
\hline & c32622_g1 & 19.969 & 163.079 & up* \\
\hline & c36002_g1 & 648.51 & 853.441 & up \\
\hline & c36002_g2 & 519.983 & 1052.36 & up \\
\hline & c39431_g1 & 160.52 & 584.483 & up* \\
\hline
\end{tabular}

Note: LOX: lipoxygenase; AOS: allene oxide synthase; AOC: allene oxide cyclase; OPR: Oxophytodienoic acid reductase.

CK: the control group cells; $\mathrm{E}_{20 \mathrm{~h}}$ : The cultured cells elicited by ANE for 20 hours.

Superscript symbol “*” indicates that this unigene expression changed significantly. 
Table 2

Summary of differentially expressed genes in JA signal transduction pathway of suspension cultured $C$. paliurus cells

\begin{tabular}{|c|c|c|c|c|}
\hline Unigene name & Unigene code & FPKM of CK & FPKM of $E_{20 h}$ & Trends \\
\hline JAR1 & c39500_g1 & 48.614 & 77.295 & up \\
\hline \multirow[t]{7}{*}{ JAZ } & c27861_g1 & 10.327 & 4.938 & down \\
\hline & c33284_g1 & 2.664 & 5.504 & up \\
\hline & c38204_g1 & 9.757 & 8.196 & down \\
\hline & c44879_g3 & 24.427 & 24.881 & up \\
\hline & c44879_g4 & 58.892 & 32.683 & down \\
\hline & c45306_g2 & 38.711 & 31.479 & down \\
\hline & c45306_g3 & 44.28 & 26.045 & down \\
\hline \multirow[t]{3}{*}{ MYC2 } & c29186_g1 & 27.69 & 21.089 & down \\
\hline & c37338_g1 & 16.89 & 14.904 & down \\
\hline & c43784_g1 & 103.877 & 85.936 & down \\
\hline \multicolumn{5}{|c|}{$\begin{array}{l}\text { Note: JAR1: JA-amino acid synthetase 1; JAZ: jasmonate ZIM domain-containing protein; MYC2: } \\
\text { myelocytomatosis protein } 2 \text {. }\end{array}$} \\
\hline
\end{tabular}

\section{Figures}




\section{Fig.1}
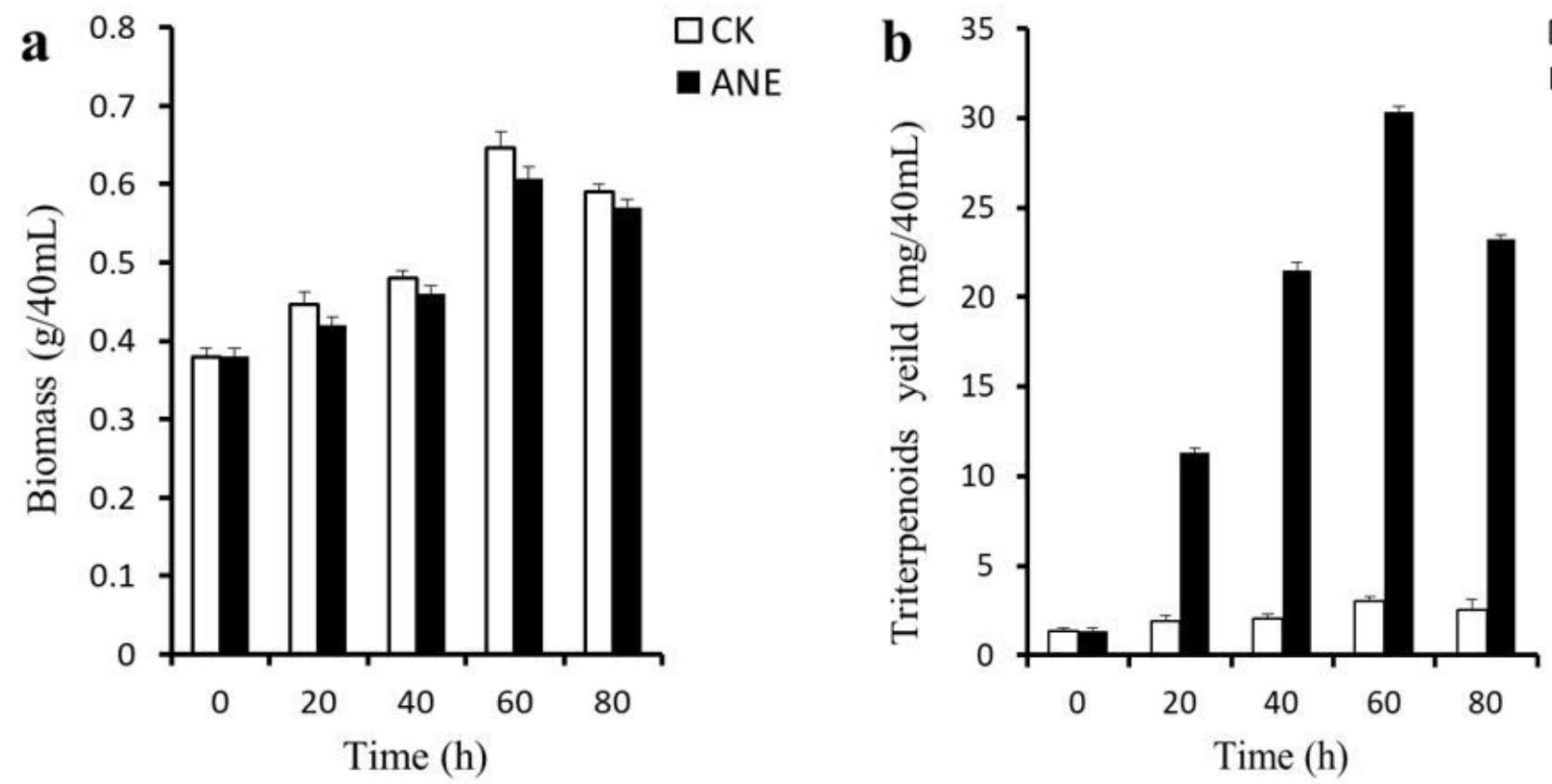

Figure 1

Comparison on biomass (a) and triterpenoids yield (b) between the ANE elicited and un-elicited C. paliurus cells. Suspension culture conditions: $\mathrm{C}$. paliurus cells were cultured in MS medium supplemented with an combined hormones ( $1.0 \mathrm{mg} / \mathrm{L} \mathrm{KT+0.5} \mathrm{mg/L} \mathrm{2,} \mathrm{4-D+0.3} \mathrm{mg/L} \mathrm{NAA),} 6 \mathrm{~g} / \mathrm{L}$ agar and $30 \mathrm{~g} / \mathrm{L}$ sucrose, and cultivated in the dark at $25 \pm 1{ }^{\circ} \mathrm{C}$ on a rotary shaker at $115 \mathrm{rpm}$. ANE elicitation parameters: ANE at a concentration of $200 \mu \mathrm{g} / \mathrm{mL}$ was added into the culture medium on the 4th day after cell inoculation; cells were respectively harvested at 0th, 20th, 40th, 60th and 80th hours after the elicitation of ANE. CK: the control group cells; ANE: The cultured cells elicited by ANE. 
Fig.2
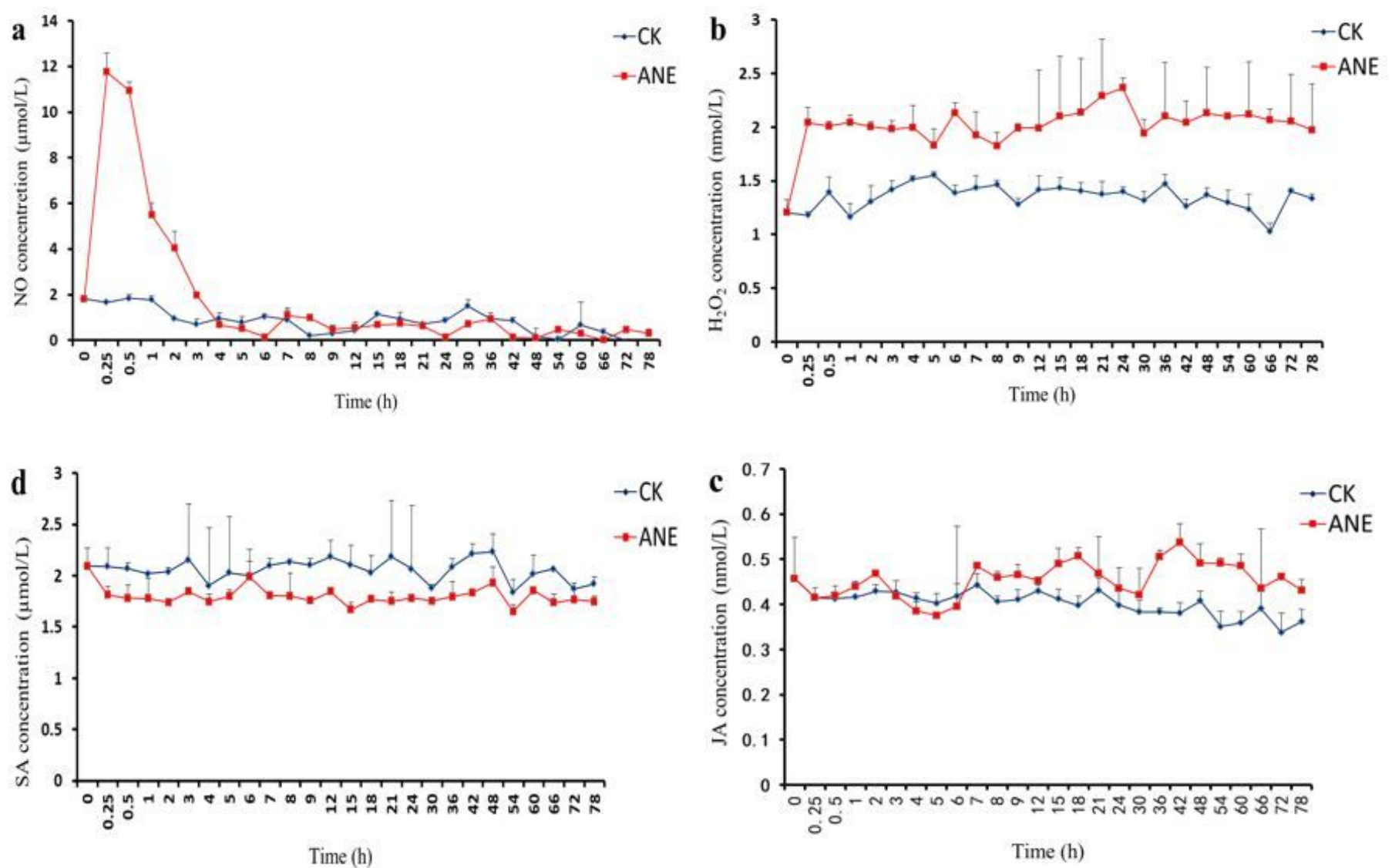

Figure 2

The change profiles of $\mathrm{NO}(\mathrm{a}), \mathrm{H} 2 \mathrm{O} 2(\mathrm{~b}), \mathrm{JA}(\mathrm{c})$ and SA (d) concentration of the suspension cultured $\mathrm{C}$. paliurus cells at different time after ANE elicitation. Suspension culture conditions: $\mathrm{C}$. paliurus cells were cultured in MS medium supplemented with an combined hormones $(1.0 \mathrm{mg} / \mathrm{L} \mathrm{KT}+0.5 \mathrm{mg} / \mathrm{L}$ 2, 4-D + 0.3 $\mathrm{mg} / \mathrm{L} \mathrm{NAA}), 6 \mathrm{~g} / \mathrm{L}$ agar and $30 \mathrm{~g} / \mathrm{L}$ sucrose, and cultivated in the dark at $25 \pm 1{ }^{\circ} \mathrm{C}$ on a rotary shaker at $115 \mathrm{rpm}$. ANE $(200 \mu \mathrm{g} / \mathrm{mL})$ was added into the culture medium on the 4th day after cell inoculation. CK: the un-elicited cells; ANE: The cultured cells elicited by ANE. 
Fig.3
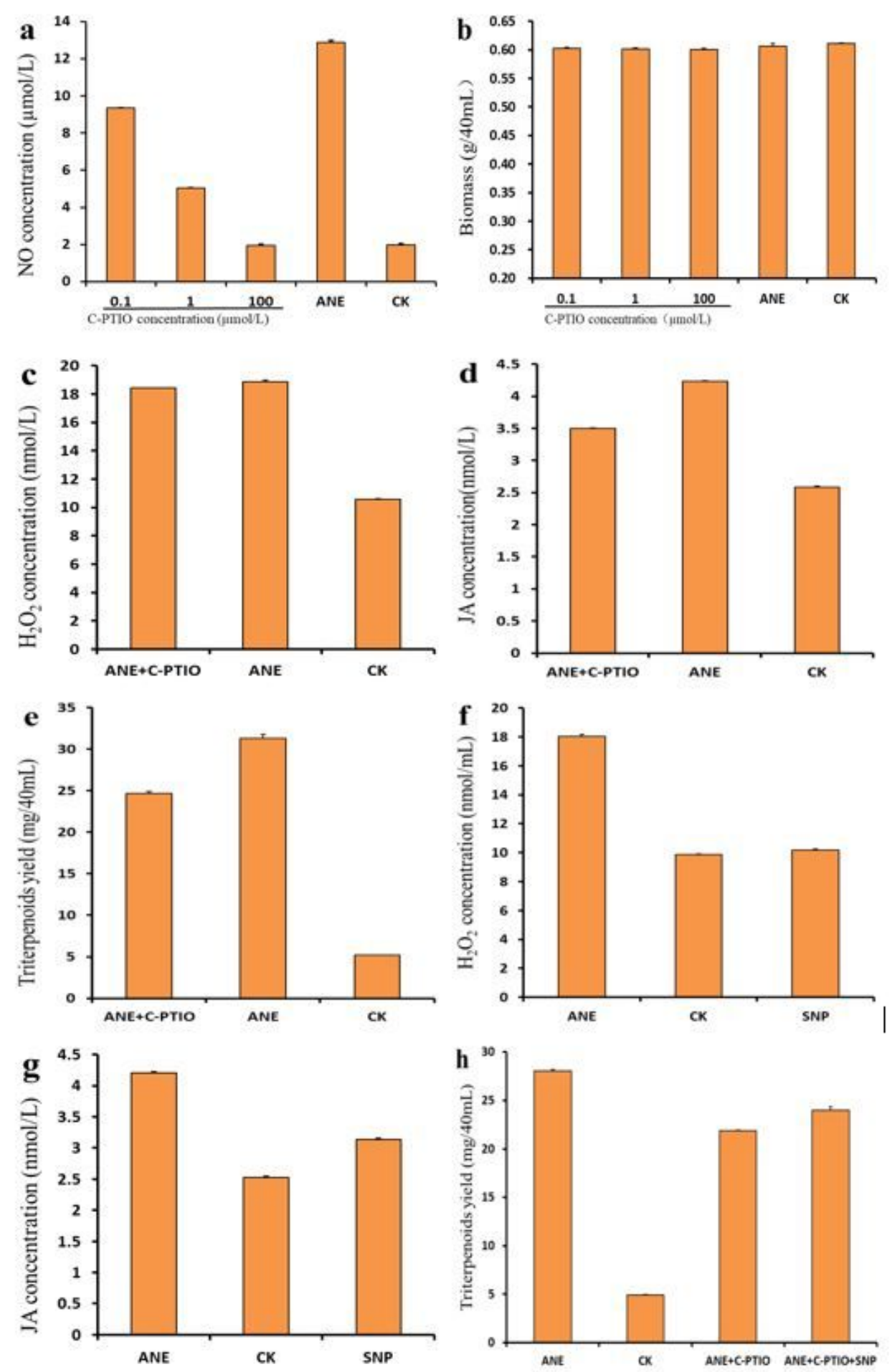

Figure 3

Change profiles of NO, $\mathrm{H} 2 \mathrm{O} 2$ and JA contents, biomass, and triterpenoids yield of the cultured C. paliurus cells causing by NO quenching and exogenous addition. a: the contents of $\mathrm{NO}$ in cultured $\mathrm{C}$. paliurus cells under different concentrations of C-PTIO; b: biomass of the cultured C. paliurus cells under different concentrations of C-PTIO; : the contents of $\mathrm{H} 2 \mathrm{O} 2$ in the ANE elicited C. paliurus cells with or without the addition of the $100 \mu \mathrm{mol} / \mathrm{L} \mathrm{C-PTIO}$; d: the contents of JA in the ANE elicited C. paliurus cells with or 
without the addition of the $100 \mu \mathrm{mol} / \mathrm{L}$ C-PTIO; e: the yield of triterpenoids in the ANE elicited C. paliurus cells with or without the addition of the $100 \mu \mathrm{mol} / \mathrm{L}$ C-PTIO; f: the contents of $\mathrm{H} 2 \mathrm{O} 2$ in the ANE or SNP (adding150 $\mu \mathrm{mol} / \mathrm{L}$ SNP, exgenous NO donor) elicited C. paliurus cells; g: the contents of JA in the ANE or SNP elicited C. paliurus cells; $h$ : the yield of triterpenoids in the ANE, ANE combined with $100 \mu \mathrm{mol} / \mathrm{L} \mathrm{C-}$ PTIO, and SNP treated C. paliurus cells CK: the control group cells; ANE: the cultured cells elicited by ANE; ANE+ C-PTIO: the cultured cells adding ANE and C-PTIO; SNP: the cultured cells adding to SNP; ANE+ CPTIO +SNP: the cultured cells adding to ANE, C-PTIO and SNP.

\section{Fig.4}
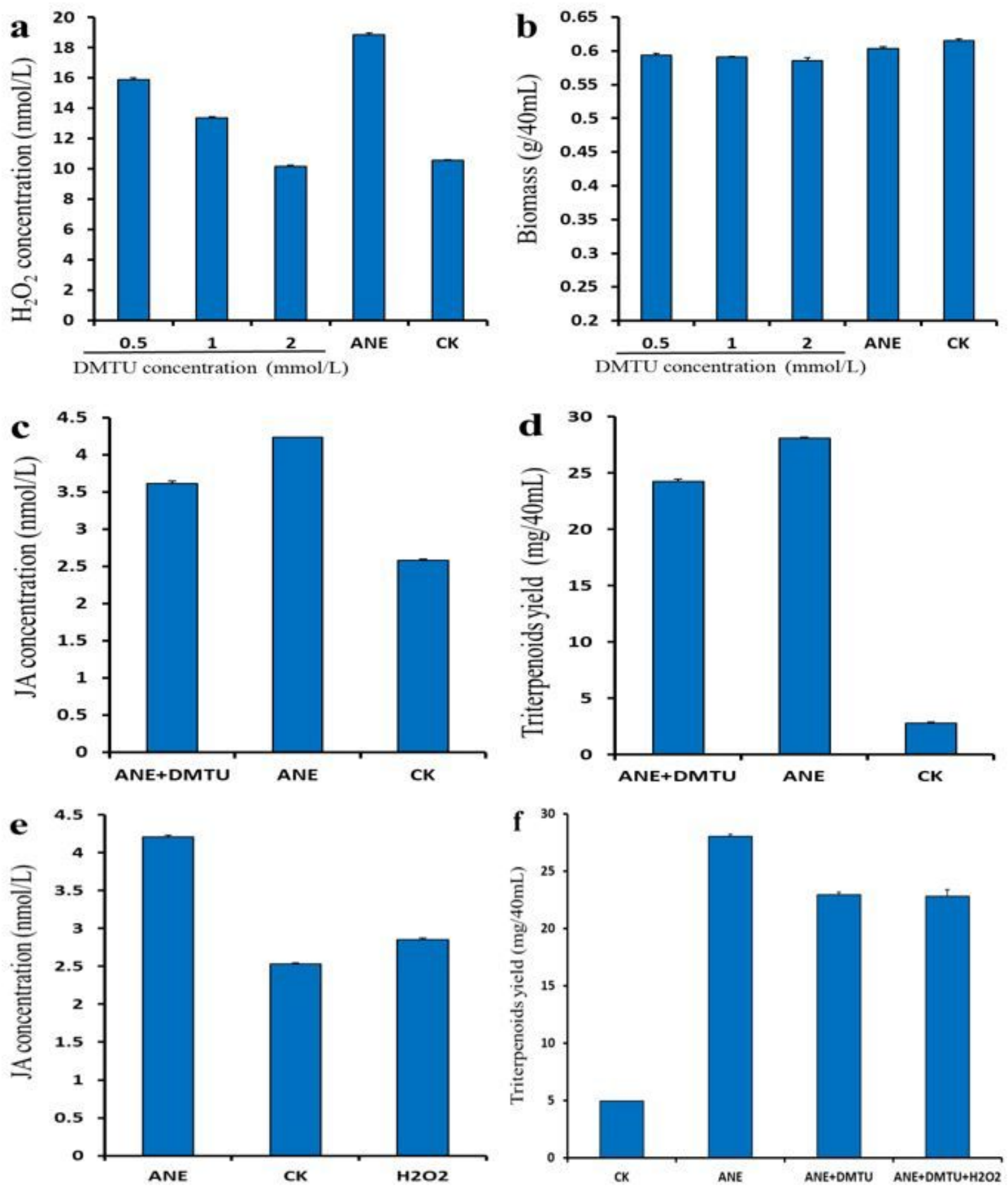
Figure 4

Change profiles of $\mathrm{H} 2 \mathrm{O} 2$ and JA contents, biomass, and triterpenoids yield of the cultured C. paliurus cells causing by $\mathrm{H} 2 \mathrm{O} 2$ blocking and exogenous addition. a: the contents of $\mathrm{H} 2 \mathrm{O} 2$ in cultured C. paliurus cells under different concentrations of DMTU; b: biomass of the cultured C. paliurus cells under different concentrations of DMTU; c: the contents of JA in the ANE elicited C. paliurus cells with or without the addition of the $2 \mathrm{mmol} / \mathrm{L} \mathrm{DMTU}$; $\mathrm{d}$ : the yield of triterpenoids in the ANE elicited C. paliurus cells with or without the addition of the $2 \mathrm{mmol} / \mathrm{L}$ DMTU; e: the contents of JA in the ANE, ANE combined with 2 $\mathrm{mmol} / \mathrm{L}$ DMTU and $50 \mu \mathrm{mol} / \mathrm{L} \mathrm{H} 2 \mathrm{O} 2$ elicited C. paliurus cells; $\mathrm{f}$ : the yield of triterpenoids in the ANE, ANE combined with $2 \mathrm{mmol} / \mathrm{L} \mathrm{DMTU}$, and $50 \mu \mathrm{mol} / \mathrm{L} \mathrm{H} 2 \mathrm{O} 2$ treated C. paliurus cells CK: the control group cells; ANE: the cultured cells elicited by ANE; ANE+ DMTU: the cultured cells adding ANE and DMTU; H2O2: the cultured cells adding H2O2; ANE+DMTU+ H2O2: the cultured cells adding ANE and DMTU.

\section{Fig.5}
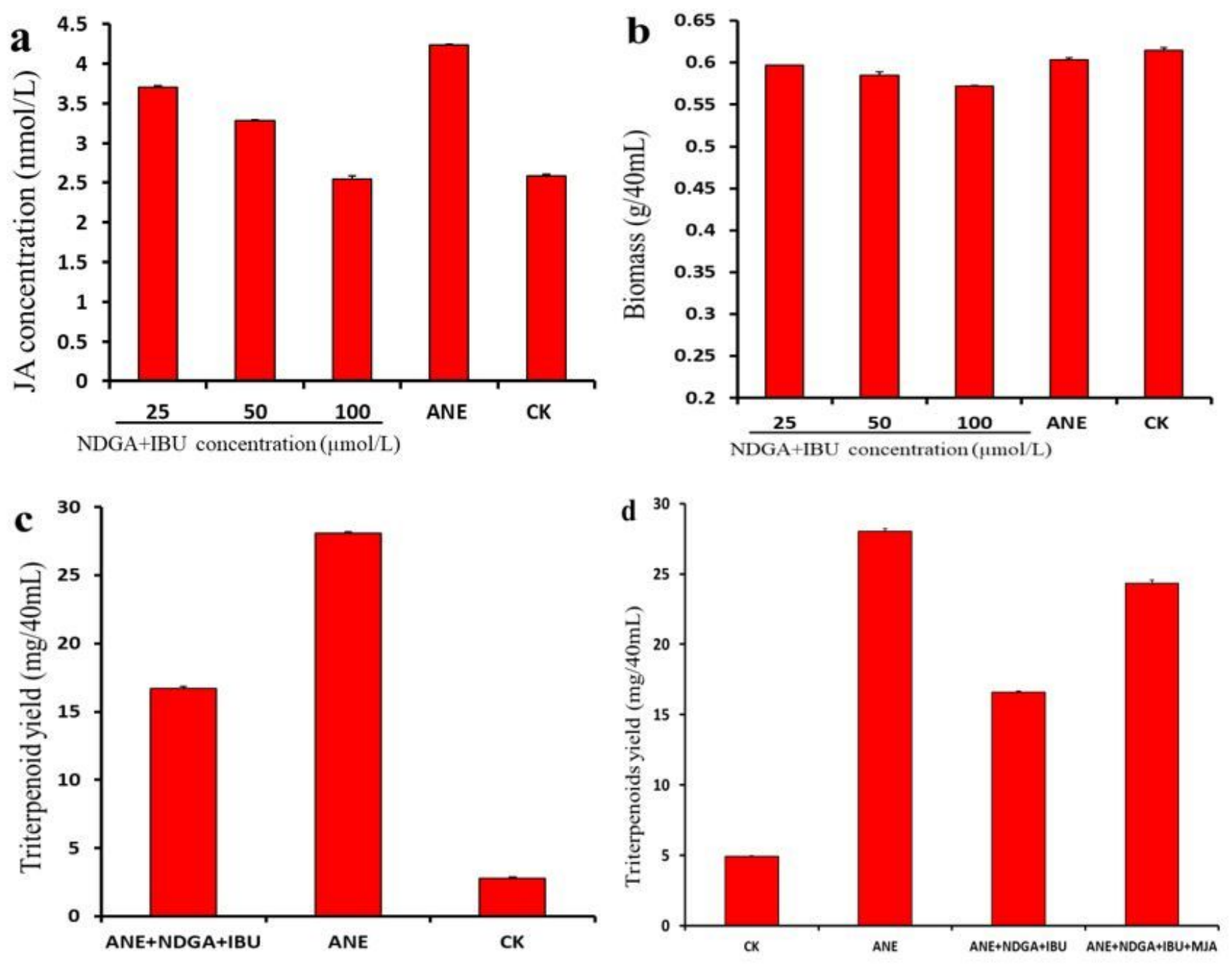

Figure 5 
Change profiles of JA contents, biomass, and triterpenoids yield of the cultured C. paliurus cells causing by JA inhibiting and exogenous addition. a: the contents of JA in cultured C. paliurus cells under different concentrations of NDGA+IBU; b: biomass of the cultured $C$. paliurus cells under different concentrations of NDGA+IBU; $\mathrm{C}$ : the yield of triterpenoids in the ANE elicited C. paliurus cells with or without the addition of the $100 \mu \mathrm{mol} / \mathrm{L}$ NDGA+IBU; d: the yield of triterpenoids in the ANE, ANE combined with $100 \mu \mathrm{mol} / \mathrm{L}$ NDGA+IBU, and MJA(additing10 $\mu \mathrm{mol} / \mathrm{L}$ MJA, exgenous JA donor) treated C. paliurus cells. CK: the control group cells; ANE: the cultured cells elicited by ANE; ANE+ NDJA+IBU: the cultured cells adding ANE and NDJA+IBU; ANE+ NDJA+IBU +MJA: the cultured cells adding ANE, NDJA+IBU and MJA.

\section{Fig.6}

Nitric Oxide

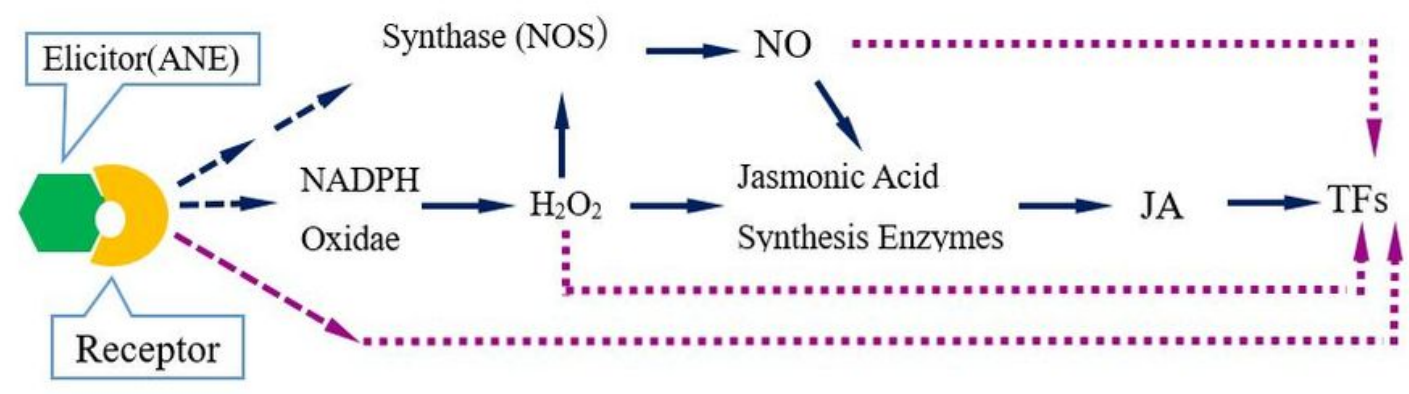

Triterpenoids

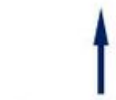

Triterpenoids

Synthesis Enzymes

\section{Figure 6}

The deduced signal transduction network of ANE elicitation in the suspension cultured C. paliurus cells. Blue arrow line (including solid line and dotted line): signal transduction pathway deduced according to the resultant analyses in the present paper; purple dotted arrow line: hypothetical signal transduction pathway.

\section{Supplementary Files}

This is a list of supplementary files associated with this preprint. Click to download.

- Supplementaryinformation.docx

- SupplementaryFigures.docx

- SupplementaryTables.docx 